\title{
Social Tourism and Healthy Ageing
}

\author{
JORDI GARCÉS FERRER ${ }^{1}$, MIREIA FERRI SANZ ${ }^{1 *}$, ESTRELLA DURÁ FERRANDIS ${ }^{1}$, SCOTT MCCABE $^{2}$ and \\ JAVIER SÁNCHEZ GARCIÁ ${ }^{3}$ \\ ${ }^{1}$ Polibienestar Research Institute, University of Valencia, Valencia, Spain \\ ${ }^{2}$ Nottingham University Business School, UK B77 North Building, Jubilee Campus, Nottingham, UK \\ ${ }^{3}$ University Jaume I, Polibienestar Research Institute, Valencia, Spain
}

\begin{abstract}
Recent research in social tourism notes possible links between tourism participation and improvements in health. However, there is a lack of quantitative evidence concerning the potential links between tourism participation and self-reported health amongst older people. An ageing society requires measures to promote independent living and enhance older people's quality of life. This paper provides evidence that older tourists are more active and healthy than non-tourists, from a study comparing health perceptions amongst Spanish older people. The results provide tentative conclusions of causal relationships between tourism and dimensions of physical and mental health through a Structural Equation Model. Copyright (C) 2015 John Wiley \& Sons, Ltd.
\end{abstract}

Received 03 July 2014; Revised 14 April 2015; Accepted 25 April 2015

KEY WORDS health; active ageing; social tourism; social policy; ICF model; social and health systems

\section{INTRODUCTION}

It is generally accepted that holiday tourism is a positive and healthy pursuit to follow in leisure time (Hobson and Dietrich, 1995), providing many benefits to mental and psychical health. Across a range of contexts, the links between holiday taking and quality of life, health, stress reduction, active life and healthy lifestyle have been demonstrated. Satisfaction with life has been shown to be linked to satisfaction with leisure travel services and experiences (Neal, Sirgy and Uysal, 1999; Sirgy 2010), and more general links between tourism and quality of life (Dolnicar et al., 2012), and subjective well-being have been made (Gilbert and Abdullah, 2004). Travel has been positively correlated with physical health outcomes (specifically, risk of cardiovascular heart disease amongst middle-aged men) (Gump and Matthews, 2000). People often feel happier, healthier and more relaxed after a pleasure trip, although these effects are limited in strength and duration after the holiday (de Bloom et al., 2011). In a recent review of the literature on the health and wellness outcomes of travel, Chen and Petrick (2013) identify a range of different approaches that have been taken to understand the links between travel and health outcomes. However, Chen and Petrick conclude that there is a relative lack of research focusing on the links between healthy and active lifestyles and travel experiences. In the context of research on senior travellers, whilst there have been many studies on the general characteristics of this market (e.g. McGuire, 1984), there are fewer which have focused on health and wellbeing relationships for this group. Notable exceptions are Milman (1998) and Wei and Milman (2002).

*Correspondence to: Ferri Sanz, Mireia, Polibienestar Research Institute, Universitat de València, Spain.

E-mail: mireia.ferri@uv.es
These studies focused on activity levels during vacation and psychological wellbeing. Milman's study was inconclusive, but Wei and Milman concluded that taking part in a variety of activities whilst on vacation might lead to wellbeing improvements.

On the other hand, older people have been identified as a group of people who can benefit from tourism experiences in research on 'Social Tourism'. Social Tourism is defined as the inclusion of disadvantaged and economically weak strata of society in tourism, most usually through the provision of financial and other forms of support (Minnaert et al., 2009). Therefore Social Tourism is differentiated from 'market' tourism by linking participation to social and health policy agendas. Indeed, there is mounting evidence linking personal and social benefits with Social Tourism participation, including the possible links to physical and mental health outcomes. For example, children from low-income families (Quinn et al., 2008) and their parents (McCabe, 2009) stated higher subjective wellbeing because of the generation of happy memories associated with Social Tourism. McCabe and Johnson (2013) identify three spheres where these families show a better self-assessment of their wellbeing because of their participation in Social Tourism programmes: satisfaction with life, satisfaction with domain aspects of their life and aspects of positive functioning. Other benefits linked to Social Tourism include better self-perceived health for specific groups of tourists (European Economic and Social Committee-EESC, 2006). For example, disabled people saw their health condition improved and increased efficiency and physical capacity following participation in tourism, leisure and sport activities (Bergier et al., 2010; Blichfeldt and Nicolaisen, 2010). Moreover, Social Tourism participation has been linked implicitly to more general improvements in personal health and social inclusion (Minnaert et al., 2009). 


\section{J. G. Ferrer et al.}

Thus Social Tourism has been identified as a possible source of intervention in social and health programmes and becomes especially relevant in the case of the elderly. It is generally accepted that Europe is living in an ageing society (Eurostat, 2010) where older people (65 or more years old) will increase as a proportion of the European populace from the current $17 \%$ to over $29.5 \%$ in 2060 (Eurostat, 2012). Moreover, this ageing process linked with the prevalence of chronic diseases will place an increasing burden on health and social care provision in the future (World Health Organisation [WHO], 2011). Initiatives that promote healthy and active ageing are receiving a growing interest because they could be beneficial in reducing the levels of dependency of older people and enhance quality of life help to improve the economic and social welfare of families, and the efficiency of social and health systems (Ferri et al., 2013).

In this context, the aim of the current study is to understand any relationships between tourism participation and health in older people, and to explore the potential of Social Tourism as part of a strategy to promote active and healthy ageing.

\section{LITERATURE REVIEW AND OBJECTIVES}

Elderly people have been drawing increased attention from tourism researchers as well as from services providers and governments because they are becoming more predominant in society (Glover and Prideaux, 2009). Today's retirees are wealthier, better educated, more independent and freer from obligations than in the past (Martin and Preston, 1994), which means that older people are more likely to prioritise tourism (Statts and Pierfelice, 2003). In fact, Weiss (2005) suggested that the ability to participate in tourism is almost the essence of retirement, whilst other authors state that retirement provides an important opportunity to take holidays (Nimrod, 2008); it is a desired long-term activity of older people (Statts and Pierfelice, 2003) making up a significant part of life upon retirement (Gibson, 2002).

This relevance of tourism to the aspirations and behaviours of older people in society has led to significant interest in market studies. Thus, there is much focus on older adult's socio-demographics and holidaying patterns, and market segmentation studies (Schröder and Widmann, 2007). Others researchers have examined personal and social factors associated with the participation in tourism of older people: income level, health, culture, lifestyle, family relationships, social relationships, accessibility barriers, etc. (Fleischer and Pizam, 2002; Lee and Tideswell, 2005; McGuire, 1984; Ortega, 1989). Most research recognises that healthy, active older people are more likely to engage in tourism and that by being active and enjoying a diverse leisure and social life through tourism is likely to improve health and wellbeing perceptions (Wei and Milman, 2002). More recent research has emphasised the need for understanding older tourists' emotions, the role that tourism plays in older people's lives and its impact on their physical and emotional wellbeing which remain largely untold (Sedgley et al., 2011).
Most studies about this last topic have been made in the area of Social Tourism, assuming that the beneficial effects of tourism on health that have been identified in socially excluded groups, such as low-income families, disabled people or people with chronic illness, also occur in elderly people. In fact, tourism today is regarded as an important aspect of social life of European citizens, and, consequently, an inability to participate has become an indicator of poverty and social exclusion (Minnaert et al., 2009).

In a first attempt to evaluate the outcomes of Social Tourism programmes, Price Waterhouse Coopers (2004) evaluated the economic impacts of the IMSERSO holiday programme for elderly people in Spain, which identified positive effects on self-reported health and quality of life of participants. In a follow-up study improvements in physical capacity were additionally noted (IMSERSO, 2011). In a similar study undertaken by the INATEL Foundation to evaluate a comparable programme in Portugal, benefits in physical and psychological health conditions were identified (de Aguiar et al., 2012). Finally, in an evaluation of a similar programme in Chile, positive aspects of physical, mental and social wellbeing were reported (Paulo et al., 2004). Moreover, these studies revealed that Social Tourism contributes to: personal development and learning; cultural enrichment and feelings of citizenship, which reinforces personal relationships (IMSERSO, 2011; de Aguiar et al., 2012; EESC, 2006). Indeed, users of Social Tourism programmes have identified the possibility for meeting new people during the holiday as one of the greatest benefits (Minnaert et al., 2009), contributing to social inclusion. For older people, social isolation is a key issue for which tourism provides an important mental health benefit (de Aguiar et al., 2012).

Previous studies indicate that the personal and social benefits arising from Social Tourism are such that it could be used as part of strategy to promote an active and healthy ageing (Ferri et al., 2013). In this context, 'health' refers to physical, mental and social wellbeing; and 'active' refers to continuing participation in social, economic, cultural, spiritual and civic affairs (European Innovation Partnership on Active and Healthy Aging, 2011).

Nevertheless, most of these studies reviewed above are insufficient because they did not employ validated scientific measures of health and wellbeing, and were mainly focused on evaluating the economic benefits of the programmes, with health used as an indicator of savings on health and social services spending. Others used qualitative tools to determine the benefits linked with tourism participation considering only one aspect of health rather than health as a global measure: physical, psychological and social wellbeing. Whilst providing valuable insights into experiences, these studies could be hampered by social desirability bias whereby people asked to identify positive outcomes of supported (funded) interventions may provide desired responses. Consequently, the lack of robust quantitative research on the benefits of Social Tourism is one of the main criticisms of the existing literature (Chen and Petrick, 2013).

Responding to this gap in knowledge, and to try to go beyond the implicit links between tourism participation and active and healthy ageing, our study aimed to examine older 
people's self-reported global assessments of their health, and to assess any differences between those that participate in tourism with those that do not, outside of the context of a holiday evaluation survey. A further aim was to test the application of standardised and validated health measures using a Structural Equation Model to understand if causal links could be established between tourism and health in this group of subjects.

\section{MATERIAL AND METHODS}

ICT model: the reference model to formulate the hypothesis of the study

According to the WHO (1946) 'health is the state of complete physical, mental and social wellbeing and not merely the absence of disease or infirmity' (p. 100). Consequently, it is a global concept that involves different aspects of the individual's life as is defined in the International Classification of Functioning, Disability and Health (ICF). The ICF tries to achieve a synthesis of medical and social models in an attempt to combine disability and functioning, in order to provide a coherent view of health domains from a biological, individual and social perspective (WHO, 2001). Concretely, the ICF proposes that the person's functioning and disability are a dynamic interaction between health conditions and contextual factors (personal and environmental) (see Figure 1).

In relation to health conditions, functional health has recently received increased attention from researchers in ageing (WHO, 2002). The functional status of an older person is defined as his/her ability to perform his/her normal activity and maintain their independence in his/her environment (Sanjoaquin et al., 2007) and is measured through the individual's self-assessment of his/her health and disability (WHO, 2002) and his/her ability to carry out the activities of daily life (Sanjoaquin et al., 2007). Amongst these activities, studies differentiate between basic and instrumental activities (Querejeta, 2004), and for this study the instrumental activities of daily life were chosen. Based on this first factor, two hypotheses were formulated:
H1: Older people who participate in tourism have better self-perceived health than older people who do not participate in tourism.

$\mathrm{H} 2$ : Older people who participate in tourism have better capacity to develop instrumental activities of daily life than older people who do not participate in tourism.

In this sense, older people's quality of life is a multidimensional concept that should also consider subjective impressions such as satisfaction with life (Iglesias-Souto and Dosil, 2005). For that reason, a third hypothesis is considered:

H3: Older people who participate in tourism are more satisfied with their lives than older people who do not participate in tourism.

Second, environmental factors are external forces that impact in the individual's functioning. The ICF model lists, amongst others: technology and products developed in society for the benefit of citizens; the natural and urban environment in which the individual lives; his/her social support and relationships and services offered by governments. Amongst these factors, our study considers social integration because it can be assessed by the individual. On this basis, the fourth hypothesis is defined:

H4: The social integration of older people who participate in tourism is greater than for those who do not participate in tourism.

Finally, personal factors consist of the particular background to an individual's life and lifestyle. These factors include gender, ethnicity, age, fitness, lifestyle, habits, education, profession, etc. (WHO, 2001). These factors were normalised in our study in order to focus solely on health factors (i.e. when socio-economic and other demographic factors are equal, are there any differences in self-reported health between those that participate in tourism and those that do not?).

As summary, our study aimed to provide evidence about the impact of tourism on health amongst older people and the links between tourism participation and active ageing.

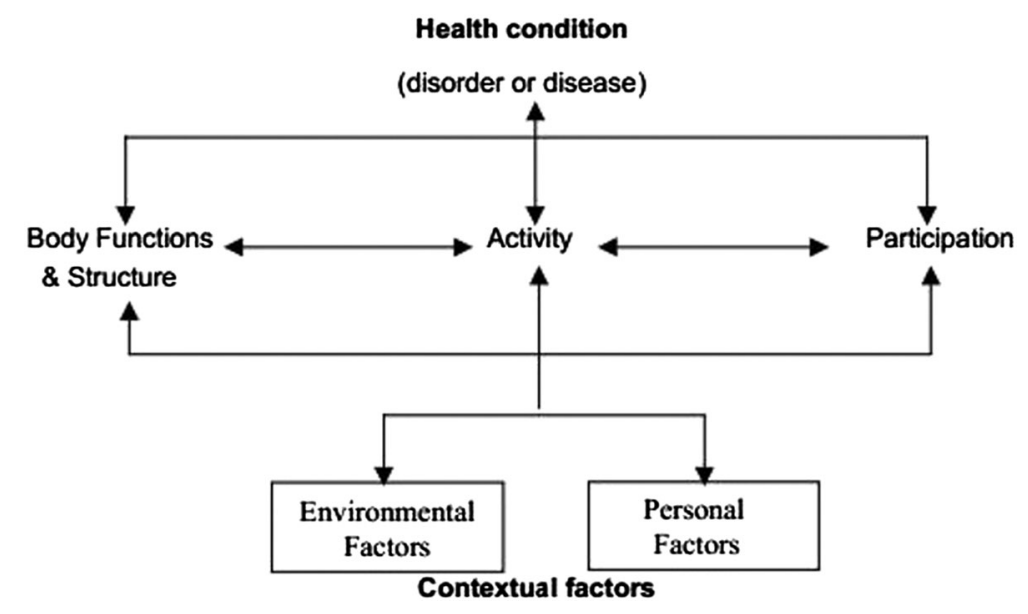

Figure 1. Diagram of the ICF model (WHO, 2011). 
This objective requires the formulation of the last hypothesis of our study:

H5: Tourism affects positively older people's health.

\section{Scales}

Based on the ICF model, standardised scales and selfdesigned instruments were used in order to measure the variables considered in our study and to test the hypothesis described in previous section:

The SF-12 (Alonso et al., 1998) was used to measure the self-perceived health status because it is one of the most widely used instruments in Spanish research (Vilagut et al., 2005). The instrument is composed of twelve likert-items that form eight domains of health that can be combined into two global values: physical and mental health. Each of these domains is scored from zero (worst health state) to 100 (better health state). This index provided a Cronbach's $\alpha$ of 0.80 for physical health and 0.66 for mental health in our study.

The Lawton and Brody (1969) index was used to evaluate the capacity of a person to carry out the instrumental activities of daily life. This index is the standard measure in geriatric research centres in Spain (Lyons et al., 2002) because of its reliability (Cronbach's $\alpha$ value of 0.87 in our study). This scale evaluates the individual's capacity to perform eight activities for women and five for men (the difference is because of the nature of the activities and the social differences that prevail in housework duties amongst elderly people). The index gives each item a value of zero (some grade of dependency) or one (independent) obtaining a final score that ranges from zero (totally dependent) to eight for women or five for men (totally independent).

The Satisfaction with Life Scale (Diener et al., 1985) measures this variable through five items on a seven-point Likert scale. This scale has been applied in many different contexts, including recently in Social Tourism research (McCabe and Johnson, 2013). In our study, the Cronbach's $\alpha$ is 0.83 .

Finally, the Berkman and Syme index (1979) assesses the individual's level of social integration on a four-point scale from most isolated (zero) to most-integrated (four). In our study the Cronbach's $\alpha$ achieved a reduced level of reliability of 0.37. This study used this index despite the reduced Cronbach's $\alpha$ because in our previous study undertaken to validate the scales with a sample of 43 older people this scale reached a Cronbach's $\alpha$ of 0.84 .

In addition to these scales, some further items were included related to the tourism habits and preferences of respondents in order to determine the differences in tourism participation. These items were used to perform a cluster analysis to obtain different groups, forming a hierarchical cluster. Once the cluster centres were obtained, a k-means cluster analysis was applied resulting in two groups: tourists and non-tourists. The 14 items used concerned trip characteristics (such as duration and accommodation used) independently of the characteristics of specific trips. To ratify the significant differences between these two groups, an
ANOVA was performed, and the results showed that significant differences existed for the mean values of the 14 variables between the two groups obtained, representing the tourist group significant higher values.

\section{Data collection and analysis}

In the study, a convenience sample of people over 65 years old were selected from six leisure centres that organise leisure activities for elderly people in the city of Valencia and surroundings (Spain). As the research focused on an evaluation of the effects of tourism participation on health, the sample was divided into tourists and non-tourists as described previously. Moreover, the original sample of 221 elderly people was reduced in order to make both groups comparable in the main socio-demographic characteristics that could impact on health. Particularly, the groups were reduced so that each was comparable in age because it is one of the demographic variables that affect the development of dependency, eliminating older respondents. Finally, 189 people between 65 and 85 years old formed the sample: 149 were considered tourists $(78.84 \%)$ and 40 non-tourists $(21.16 \%)$. Their characteristics are described in Table 1.

The method of data collection was a self-administered questionnaire supplemented in some cases with personal interviews when the participants had problems reading and understanding the questions. Respondents consented to their participation by signing an informed consent statement. This document gave specific information on the research organisation, the aims and legal aspects in relation with the study such as anonymity of data, right to withdraw at any time from the research, etc. As mentioned, standardised scales and self-designed instruments were combined in the questionnaire with a total of 68 questions that take $35 \mathrm{~min}$ to participants to complete it.

Data analysis was carried out using the SPSS Statistics Version 19 and the EQS 6.1 Structural Equations. Descriptive analyses were run in order to determine the health characteristics of the sample. Bivariate comparative tests (T-Student and Chi-Squared) were also carried out between the two groups to detect significant differences on their health. Finally, a Structural Equations Model (SEM) was developed to evaluate the impact of tourism on elderly people considering the health variables measured. T-Student and Chi-Squared tests for continuous and categorical variables were respectively set at 0.05 significance, and for the EQS programme the rules of Bentler (2006) were followed.

The database was treated and no missing data were observed, so complete cases were used. The descriptive statistics are presented in Table 2.

\section{FINDINGS}

\section{Comparing health perceptions amongst tourists and non-tourists}

First, the SF-12 revealed that the tourist group had a higher average score for physical and mental health than nontourists. These differences are statistically significant for both 
Table 1. Socio-demographic characteristics of respondents

\begin{tabular}{|c|c|c|c|c|c|c|c|c|c|}
\hline \multirow{3}{*}{$\overline{\text { Gender }}$} & \multirow[b]{3}{*}{ Male } & \multirow{2}{*}{\multicolumn{2}{|c|}{$\begin{array}{l}\text { Sample } \\
(\mathrm{N}=189)\end{array}$}} & \multirow{2}{*}{\multicolumn{2}{|c|}{$\begin{array}{l}\text { Older tourists } \\
\qquad(\mathrm{N}=149)\end{array}$}} & \multirow{2}{*}{\multicolumn{2}{|c|}{$\begin{array}{l}\text { Older non-tourists } \\
\qquad(\mathrm{N}=40)\end{array}$}} & \multicolumn{2}{|c|}{$\begin{array}{c}\text { Differences } \\
\text { (tourists/non-tourists) }\end{array}$} \\
\hline & & & & & & & & \multirow{2}{*}{$\begin{array}{c}\chi^{2 / t} \\
\chi^{2}=0.648\end{array}$} & \multirow{2}{*}{$\begin{array}{c}\mathrm{p} \\
0.421\end{array}$} \\
\hline & & 62 & $32.80 \%$ & 51 & $34.23 \%$ & 11 & $27.50 \%$ & & \\
\hline & Female & 127 & $67.20 \%$ & 98 & $65.77 \%$ & 29 & $72.50 \%$ & & \\
\hline Age & Average & & 73.76 & & 73.24 & & 75.7 & $\mathrm{t}=-2.568$ & 0.110 \\
\hline \multirow{6}{*}{ Marital status } & Single & 9 & $4.76 \%$ & 8 & $5.37 \%$ & 1 & $2.50 \%$ & \multirow{6}{*}{$\chi^{2}=4.952$} & \\
\hline & Divorced & 7 & $3.70 \%$ & 5 & $3.36 \%$ & 2 & $5.00 \%$ & & 0.292 \\
\hline & Married & 121 & $64.02 \%$ & 99 & $66.44 \%$ & 22 & $55.00 \%$ & & \\
\hline & Widow/er & 45 & $23.81 \%$ & 31 & $20.81 \%$ & 14 & $35.00 \%$ & & \\
\hline & Separated & 2 & $1.06 \%$ & 1 & $0.67 \%$ & 1 & $2.50 \%$ & & \\
\hline & NR & 5 & $2.65 \%$ & 5 & $3.36 \%$ & 0 & $0.00 \%$ & & \\
\hline \multirow{9}{*}{$\begin{array}{l}\text { Highest grade } \\
\text { of education } \\
\text { completed }\end{array}$} & Incomplete primary & 78 & $41.27 \%$ & 56 & $37.58 \%$ & 22 & $55.00 \%$ & \multirow{9}{*}{$\chi^{2}=5.861$} & \\
\hline & High school graduate & 44 & $23.28 \%$ & 37 & $24.83 \%$ & 7 & $17.50 \%$ & & 0.556 \\
\hline & $\begin{array}{l}\text { Vocational training } \\
\text { of } 1 \text { course }\end{array}$ & 8 & $4.23 \%$ & 7 & $4.70 \%$ & 1 & $2.50 \%$ & & \\
\hline & $\begin{array}{l}\text { Vocational training } \\
\text { of } 2 \text { course }\end{array}$ & 4 & $2.12 \%$ & 4 & $2.68 \%$ & 0 & $0.00 \%$ & & \\
\hline & Bachelor degree & 24 & $12.70 \%$ & 19 & $12.75 \%$ & 5 & $12.50 \%$ & & \\
\hline & Three years degree & 8 & $4.23 \%$ & 6 & $4.03 \%$ & 2 & $5.00 \%$ & & \\
\hline & Five years degree & 9 & $4.76 \%$ & 8 & $5.37 \%$ & 1 & $2.50 \%$ & & \\
\hline & Master or PhD & 3 & $1.59 \%$ & 3 & $2.01 \%$ & 0 & $0.00 \%$ & & \\
\hline & NR & 11 & $5.82 \%$ & 9 & $6.04 \%$ & 2 & $5.00 \%$ & & \\
\hline \multirow[t]{8}{*}{ Income source } & Wage & 3 & $1.59 \%$ & 2 & $1.34 \%$ & 1 & $2.50 \%$ & \multirow[t]{8}{*}{$\chi^{2}=5.621$} & \\
\hline & Unemployed pension & 3 & $1.59 \%$ & 3 & $2.01 \%$ & 27 & $67.50 \%$ & & 0.467 \\
\hline & Retirement pension & 138 & $73.02 \%$ & 111 & $74.50 \%$ & 0 & $0.00 \%$ & & \\
\hline & Invalidity pension & 5 & $2.65 \%$ & 4 & $2.68 \%$ & 1 & $2.50 \%$ & & \\
\hline & Widow/er's pension & 19 & $10.05 \%$ & 14 & $9.40 \%$ & 5 & $12.50 \%$ & & \\
\hline & $\begin{array}{l}\text { Partner's retirement } \\
\text { pension }\end{array}$ & 1 & $0.53 \%$ & 1 & $0.67 \%$ & 0 & $0.00 \%$ & & \\
\hline & Nothing & 3 & $1.59 \%$ & 1 & $0.67 \%$ & 2 & $5.00 \%$ & & \\
\hline & NR & 17 & $8.99 \%$ & 13 & $8.72 \%$ & 4 & $10.00 \%$ & & \\
\hline \multirow{6}{*}{$\begin{array}{l}\text { Income level } \\
\text { (per month) }\end{array}$} & Less than $532.51 €$ & 30 & $15.87 \%$ & 22 & $14.77 \%$ & 8 & $20.00 \%$ & \multirow[t]{6}{*}{$\chi^{2}=1.839$} & \\
\hline & $\begin{array}{l}\text { Between } 532.51 € \text { and } \\
1.062 .02 €\end{array}$ & 67 & $35.45 \%$ & 52 & $34.90 \%$ & 15 & $37.50 \%$ & & 0.765 \\
\hline & $\begin{array}{l}\text { Between } 1.062 .02 € \text { and } \\
1.597 .53 €\end{array}$ & 22 & $11.64 \%$ & 18 & $12.08 \%$ & 4 & $10.00 \%$ & & \\
\hline & $\begin{array}{l}\text { Between } 1.597 .53 € \text { and } \\
2.130 .04 €\end{array}$ & 18 & $9.52 \%$ & 16 & $10.74 \%$ & 2 & $5.00 \%$ & & \\
\hline & More than $2.130 .04 €$ & 4 & $2.12 \%$ & 3 & $2.01 \%$ & 1 & $2.50 \%$ & & \\
\hline & NR & 48 & $25.40 \%$ & 38 & $25.50 \%$ & 10 & $25.00 \%$ & & \\
\hline
\end{tabular}

Notes: NR means no response; $\chi^{2}$ means Chi-square test; $\mathrm{t}$ means t-Student test; $\mathrm{p}$ means p-value.

Table 2. Descriptive statistics of variables

\begin{tabular}{|c|c|c|c|c|c|c|c|c|c|}
\hline & \multirow{2}{*}{$\begin{array}{c}\mathrm{N} \\
\text { Statistic }\end{array}$} & \multirow{2}{*}{$\begin{array}{l}\text { Mean } \\
\text { Statistic }\end{array}$} & \multirow{2}{*}{$\begin{array}{l}\text { Std. deviation } \\
\text { Statistic }\end{array}$} & \multicolumn{2}{|c|}{ Skewness } & \multicolumn{2}{|c|}{ Kurtosis } & \multirow[b]{2}{*}{ Minimum } & \multirow[b]{2}{*}{ Maximum } \\
\hline & & & & Statistic & Std. error & Statistic & Std. error & & \\
\hline Satisfaction with life & 189 & 26.32 & 5.14 & -.84 & .18 & $1 ., 1$ & .35 & 5 & 35 \\
\hline Physical health & 189 & 59.72 & 23.07 & -.62 & .18 & -.24 & .35 & 0 & 100 \\
\hline Mental health & 189 & 68.12 & 18.31 & -.82 & .18 & 1.76 & .35 & 0 & 100 \\
\hline Social integration & 189 & 1.69 & .91 & -.38 & .18 & -.59 & .35 & 0 & 4 \\
\hline Capacity to develop IADL & 189 & 6.35 & 1.73 & -.66 & .18 & -.71 & .35 & 0 & $\begin{array}{l}5 \text { for men } \\
\text { and } 8 \text { for } \\
\text { women }\end{array}$ \\
\hline Valid N (listwise) & 189 & & & & & & & & \\
\hline
\end{tabular}

dimensions (Table 3). Moreover, the minimum values reached by non-tourists in both dimensions were below the reference values established by the study of Ware et al. (2009) (4.62 for physical health and 1.32 for mental health), which did not happen with the tourists. Considering the eight health dimensions of the SF-12 the results showed that older people who participate in tourism reported higher levels of health than non-tourists in all the dimensions. So, the first hypothesis of our study is confirmed. However, these differences were only statistically significant $(p<0.05)$ in five 
Table 3. Self-percevied health of respondents comparing tourists and non-tourists

\begin{tabular}{|c|c|c|c|c|c|c|}
\hline & & & Average & S.D. & $\mathrm{t}$ & $\mathrm{P}$ \\
\hline \multirow[t]{4}{*}{ Global values } & \multirow[t]{2}{*}{ Physical health } & Tourists $(n=149)$ & 62.44 & 20.00 & \multirow[t]{2}{*}{3.21} & \\
\hline & & Non-tourists $(n=40)$ & 49.57 & 30.24 & & $0.02^{*}$ \\
\hline & \multirow[t]{2}{*}{ Mental health } & Tourists $(n=149)$ & 70.15 & 15.51 & \multirow[t]{2}{*}{2.10} & \multirow[t]{2}{*}{$0.03^{*}$} \\
\hline & & Non-tourists $(n=40)$ & 60.57 & 25.09 & & \\
\hline \multirow{16}{*}{ Dimensions } & \multirow[t]{2}{*}{ General health } & Tourists $(n=149)$ & 44.13 & 19.58 & \multirow[t]{2}{*}{2.82} & \multirow[t]{2}{*}{$0.01^{*}$} \\
\hline & & Non-tourists $(\mathrm{n}=40)$ & 33.75 & 24.38 & & \\
\hline & \multirow[t]{2}{*}{ Physical functioning } & Tourists $(n=149)$ & 67.52 & 28.36 & \multirow[t]{2}{*}{3.35} & \multirow[t]{2}{*}{$0.00^{*}$} \\
\hline & & Non-tourists $(\mathrm{n}=40)$ & 49.39 & 37.20 & & \\
\hline & \multirow[t]{2}{*}{ Role-physical } & Tourists $(n=149)$ & 65.35 & 29.46 & \multirow[t]{2}{*}{1.21} & \multirow[t]{2}{*}{0.23} \\
\hline & & Non-tourists $(n=40)$ & 58.82 & 33.10 & & \\
\hline & \multirow{2}{*}{ Role-emotional } & Tourists $(n=149)$ & 73.16 & 26.50 & \multirow{2}{*}{1.15} & \multirow[t]{2}{*}{0.25} \\
\hline & & Non-tourists $(n=40)$ & 67.52 & 31.25 & & \\
\hline & \multirow[t]{2}{*}{ Bodily pain } & Tourists $(n=149)$ & 72.76 & 29.29 & \multirow[t]{2}{*}{2.90} & \multirow[t]{2}{*}{$0.00^{*}$} \\
\hline & & Non-tourists $(\mathrm{n}=40)$ & 56.30 & 40.20 & & \\
\hline & \multirow[t]{2}{*}{ Mental functioning } & Tourists $(n=149)$ & 68.86 & 19.14 & \multirow[t]{2}{*}{3.25} & \multirow[t]{2}{*}{$0.00^{*}$} \\
\hline & & Non-tourists $(n=40)$ & 56.89 & 25.83 & & \\
\hline & \multirow[t]{2}{*}{ Vitality } & Tourists $(n=149)$ & 63.99 & 22.70 & \multirow[t]{2}{*}{1.76} & \multirow[t]{2}{*}{0.08} \\
\hline & & Non-tourists $(n=40)$ & 55.93 & 34.67 & & \\
\hline & \multirow[t]{2}{*}{ Social functioning } & Tourists $(\mathrm{n}=149)$ & 74.58 & 26.16 & \multirow[t]{2}{*}{2.47} & \multirow[t]{2}{*}{$0.01^{*}$} \\
\hline & & Non-tourists $(n=40)$ & 61.95 & 36.85 & & \\
\hline
\end{tabular}

Note: $\mathrm{t}$ means t-Student test; $\mathrm{p}$ means p-value. The significant differences at 0.05 are marked with ${ }^{*}$.

dimensions: general health, physical functioning, bodily pain, mental functioning and social functioning (Table 3).

Second, elderly people's functional capacity was analysed and compared between both groups using the Lawton and Brody index. Results showed that both female and male tourists had higher values, near total independence (women: $\bar{X}$ $=7.48$; S.D. $=0.90 ;$ men $\bar{X}=4.56$; S.D. $=0.72$ ), than nontourists who scored moderate dependence levels (women $\bar{X}$ $=6.57$; S.D. $=1.80 ;$ men: $\bar{X}=3.95 ;$ S.D. $=1.14)$. In both cases, the analysis revealed that tourists had statistically significant better capacity to carry out the instrumental activities of daily life than non-tourists $(\mathrm{p}<0.05)$, confirming the hypothesis $\mathrm{H} 2$ of our study. Considering the four levels of dependency established by the index (Table 4), results revealed that significant differences were found for women $(p<0.05)$ confirming that female tourists were more independent (68.37\% total independence) than non-tourists $(41.38 \%)$ to develop the instrumental activities of daily life. Although, no significant differences were observed for men, male tourists were more independent (68.63\% total independence) than non-tourists $(45.45 \%)$.

Third, satisfaction with life was measured with the Diener scale. The results did not reveal significant differences between both groups $(p>0.05)$ (Table 5). However, the percentage of people who recorded greater satisfaction (slightly satisfied and above) were higher amongst tourists, whilst those who indicated less satisfaction (slightly dissatisfied and lower) were higher amongst non-tourists (Table 5) in line with the hypothesis 3 of our study.

Regarding social integration, the results of the Berkman and Syme index did not offer significant differences between elderly tourists and non-tourists ( $p>0.05)$; both groups were in the medium grade of integration (Table 6). Hypothesis 4 of our study is not confirmed.

Linking health to tourism participation by older people Finally, the variables were combined in an SEM in order to test if tourism affects older people's health (see Figure 2). The Chi-Square achieved (Satorra Bentler $X^{2}(5)=5.8927$ ) indicates the adaptation $(p>0.05)$ that means the existence of a global fit of the model. This model also achieves the following indicators that confirm its validity; Comparative Fit Index $(\mathrm{CFI})=0.972$, Bentler-Bonett Non-Normed Fit Index $(\mathrm{NNFI})=0.917$ and Root-Mean-Square Error of Approximation $($ RMSEA $)=0.052$ with a confidence interval of $90 \%$ (CI) $[0.027,0.077]$.

As Figure 2 reveals, social integration is not affected significantly by tourism $(\mathrm{t}<1.96)$, whilst the analysis confirms

Table 4. Capacity of carrying out the instrumental activities of daily life of respondents considering gender between tourists and non-tourists

\begin{tabular}{|c|c|c|c|c|c|c|c|c|c|c|}
\hline & \multicolumn{4}{|c|}{ Men $(n=62)$} & \multirow{3}{*}{$\begin{array}{l}\text { Chi-square } \\
\text { tests }\end{array}$} & \multicolumn{4}{|c|}{ Women $(\mathrm{n}=127)$} & \multirow{3}{*}{$\begin{array}{c}\text { Chi-square } \\
\text { tests }\end{array}$} \\
\hline & \multicolumn{2}{|c|}{ Tourists $(\mathrm{n}=51)$} & \multicolumn{2}{|c|}{ Non-tourists $(\mathrm{n}=11)$} & & \multicolumn{2}{|c|}{ Tourists $(\mathrm{n}=98)$} & \multicolumn{2}{|c|}{ Non-tourists $(n=29)$} & \\
\hline & $\mathrm{n}$ & $\%$ & $\mathrm{n}$ & $\%$ & & $\mathrm{n}$ & $\%$ & $n$ & $\%$ & \\
\hline Maximum dependent & 0 & 0.00 & 0 & 0.00 & $\chi^{2}=2.21$ & 0 & 0.00 & 0 & 0.00 & $\chi^{2}=10.81$ \\
\hline Severe dependence & 2 & 3.92 & 1 & 9.09 & $\mathrm{p}=3.31$ & 1 & 1.02 & 3 & 10.34 & $\mathrm{p}=0.04^{*}$ \\
\hline Moderate dependence & 14 & 27.45 & 5 & 45.45 & & 30 & 30.61 & 14 & 48.28 & \\
\hline Total independency & 35 & 68.63 & 5 & 45.45 & & 67 & 68.37 & 12 & 41.38 & \\
\hline
\end{tabular}

Note: $\chi^{2}$ means Chi-square test; $p$ means p-value. The significant differences at 0.05 are marked with *. 
Table 5. Satisfaction with life of respondents comparing tourists and non-tourists and between them and the reference value

\begin{tabular}{|c|c|c|c|c|}
\hline & \multicolumn{2}{|c|}{$\begin{array}{l}\text { Tourists } \\
(\mathrm{n}=149)\end{array}$} & \multicolumn{2}{|c|}{$\begin{array}{l}\text { Non-tourists } \\
\quad(\mathrm{n}=40)\end{array}$} \\
\hline & $\mathrm{n}$ & $\%$ & $\mathrm{n}$ & $\%$ \\
\hline Extremely satisfied & 40 & 26.85 & 9 & 22.50 \\
\hline Satisfied & 78 & 52.35 & 19 & 47.50 \\
\hline Slightly satisfied & 19 & 12.75 & 4 & 10.00 \\
\hline Slightly dissatisfied & 8 & 2.68 & 5 & 12.50 \\
\hline Dissatisfied & 4 & 0 & 3 & 7.5 \\
\hline $\bar{X}$ & 26.62 & & 25.24 & \\
\hline S.D. & 4.89 & & 5.92 & \\
\hline \multirow{2}{*}{$\begin{array}{l}\text { t-test between } \\
\text { tourists and } \\
\text { non-tourists }\end{array}$} & & $\mathrm{t}=1.512$ & & \\
\hline & & $p=0.132$ & & \\
\hline
\end{tabular}

Note: $\mathrm{t}$ means t-Student test; $\mathrm{p}$ means $\mathrm{p}$-value.

Table 6. Social integration of respondents comparing tourists and non-tourists

\begin{tabular}{|c|c|c|c|c|c|}
\hline \multirow{2}{*}{$\begin{array}{l}\text { Level of social } \\
\text { integration }\end{array}$} & \multicolumn{2}{|c|}{ Tourists } & \multicolumn{2}{|c|}{ Non-tourists } & \multirow{2}{*}{$\begin{array}{l}\text { Chi-square test } \\
\text { between tourist } \\
\text { and non-tourist }\end{array}$} \\
\hline & $\mathrm{n}$ & $\%$ & $\mathrm{n}$ & $\%$ & \\
\hline Lov & 56 & 37.58 & 12 & 30.00 & $\chi^{2}=0.89$ \\
\hline Mediuı & 67 & 44.97 & 21 & 52.50 & \\
\hline Medium-high & 26 & 17.45 & 7 & 17.50 & \\
\hline High & 0 & 0.00 & 0 & 0.00 & $p=0.64$ \\
\hline
\end{tabular}

Note: $\chi^{2}$ means Chi-square test; $\mathrm{p}$ means p-value.

the significant impact of tourism participation on the rest of the variables $(t>1.96)$. In this sense, tourism positively influences perceptions of satisfaction with life (standardised = $0.70 ; \mathrm{R}^{2}=0.496$ ), self-perceived health (standardised $=0.78$; $\mathrm{R}^{2}=0.603$ ) and the capacity to develop instrumental activities of daily life (standardised $=0.46 ; \mathrm{R}^{2}=0.216$ ). This result confirms the fifth hypothesis of our study.

\section{DISCUSSION AND CONCLUSIONS}

This paper provides quantitative evidence to demonstrate that older people who participate in tourism report better global health. The results in our study, comparing tourist and non-tourist groups, showed that elderly tourists had better self-perceived physical and mental health, better capacity to carry out instrumental activities of daily life, and were more satisfied with their life than non-tourists, although in the latter case the differences did not reach statistical significance. These results confirm the three first hypotheses of the study. However, the cross-comparative design of our study does not allow us to assert a causal relationship between tourism and health; therefore we used a methodological analysis that goes beyond comparative analysis and allows some causal inferences: the Structural Equation Model (SEM). SEM is becoming an increasing popular statistical tool because it allows researchers to test and predict hypotheses that approximate observed realities (Bagozzi and $\mathrm{Yi}, 2012$ ) and it is considered one of the most widely used statistical tools for testing complex models that involve relations between several variables (Heene et al., 2011).

In our study, the SEM was used to test the potential causal influence of tourism in the health of older people. The results of SEM revealed that tourism positively influences satisfaction with life, self-perceived health (physical and mental), and the capacity to develop the activities of daily life. Consequently, our study shows for the first time the potential causal relationships between tourism and health for older people and, consequently, confirms our fifth hypothesis: tourism affects positively older people's health. Our results provide quantitative evidence to support previous qualitative research findings on the health benefits of older people's participation in Social Tourism programmes such as the IMSERSO holidays in Spain, the Senior Tourism Programme in Portugal and the similar one in Chile (de Aguiar et al., 2012; IMSERSO, 2011; Paulo et al., 2004; Price Waterhouse

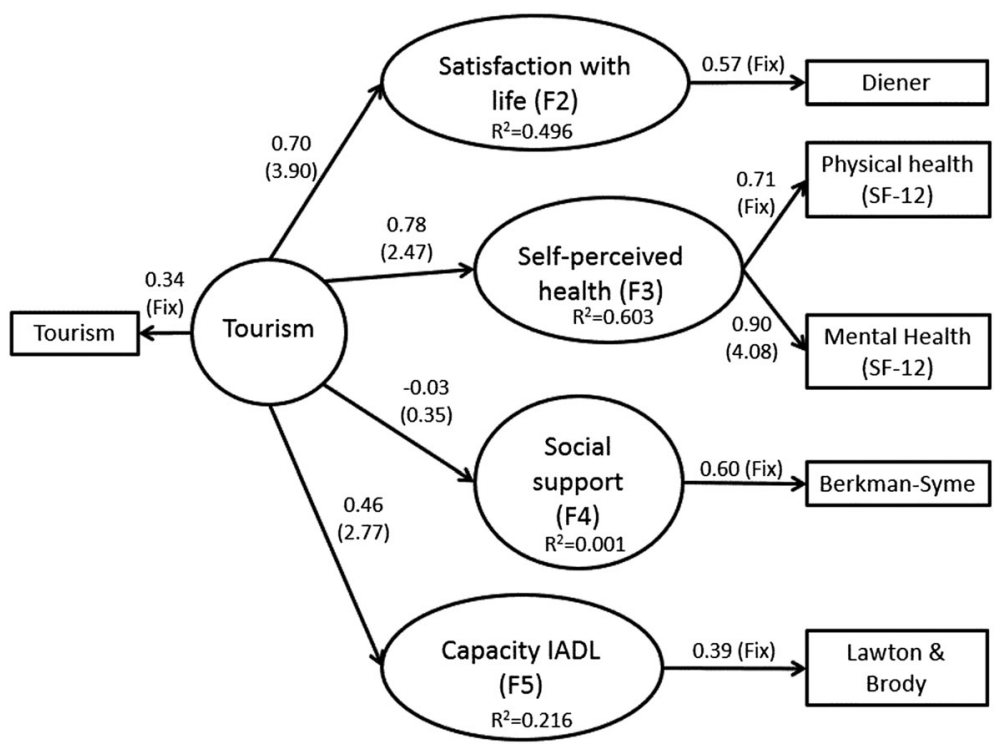

Figure 2. Contrasted model with EQS. 
Coopers, 2004), thereby enabling more scientific evidence on the relationship between tourism and health in elderly people.

Moreover, our study supports related results regarding the effects of physical activity on health in elderly people (Matsuo et al., 2003). In older age, if individuals are healthy and active, they are more likely to participate in tourism, and participation in activities such as tourism or during holidays is likely to contribute to active and healthy ageing (Alén et al., 2010; Wei and Milman, 2002). Yet there have been few attempts made to establish these links empirically. Our results indicate that participation in holidays implies the utilisation of physical and cognitive activities/processes and resources/capacities that contribute to active and healthy lifestyles. Therefore older people who do not participate in tourism could benefit from participation in order to improve physical and mental health and contribute towards societal goals for an active and healthy life in older age.

This indicates the potential impact of tourism participation on the consumption of health and social resources, in the form of savings for governments and families. Elderly tourists have better health and that can imply less use of health services in comparison with older non-tourists. This is increasingly important because of the challenges that an ageing society places on health and social care, because increases in life expectancy are not always correlated with health, hence the importance of active ageing. In 2011 , the number of healthy life years at birth was estimated at 61.8 years for men and 62.2 for women in the EU-27, which represented approximately $80 \%$ and $75 \%$ of the total life expectancy for men and women (Eurostat, 2013). In response, governments should be aware of the need to make adaptations to the public realm to account for the accessibility requirements of this population and respond to their increasing needs for long-term care (Garcés et al., 2004; Garcés and Mosonis, 2013). In fact, in the EU-27 the expenditure in long-term care is expected to increase from $1.20 \%$ in 2007 to $2.50 \%$ of the Gross Domestic Product in 2060 (European Commission, 2009). Thus, governments will need to consider a range of options to balance the need to promote active and independent living in older life and alternative health promotion to mitigate the pressures on the welfare state. One such option might include Social Tourism initiatives to promote active and healthy ageing.

Besides these health benefits, Social Tourism initiatives targeting the elderly, alongside the general tourism market for older people, are seen as important segments for the tourism sector because of the value of spending outside the peak seasons, thus contributing to sustainable employment in the sector (EESC, 2006). As numbers of older people in the market increase, their consumption patterns and preferences will have a significant influence on overall tourism demand (Glover and Prideaux, 2009). Some authors have argued that the tourism sector should adapt its supply to the needs and requirements of this growing market, including the development of age-friendly cities, to promote wellbeing (Ferri, 2013).
Consequently, Social Tourism has been shown to be effective in producing personal benefits and at the same time generating social and economic benefits for various sectors, activities and groups (EESC, 2006). For example, compared with the cost of other social measures pursuing the same objectives, Minnaert and Schapmans (2009) argued that Social Tourism can be considered as an efficient measure. The results of our study suggest that Social Tourism programmes aimed specifically at encouraging participation amongst older people may provide a useful way to health promotion strategies and contribute to active ageing policy.

However, longitudinal research comparing health of elderly people should be developed to assess which health variables change as consequence of tourism trips and the duration of the effects over time. As Chen and Petrick note in their review (2013), more evidence is needed to demonstrate the association between travel and health particularly with the use of objective measures of health (e.g. physiological measures such as blood pressure, serum cholesterol, body mass index and salivary cortisol). We have used selfreport measures of health, but we consider that our study makes significant contributions to this topic connecting tourism and perceived health in elderly people, and presents a useful methodological route to future longitudinal research. It is recognised that the cross-comparative design of our study does not allow us to categorically make causal relationships between health and tourism participation, but our study does add greater detail and depth to knowledge on these links. Moreover, the SEM model does suggest that cautiously, potential causal relationships do exist between participation in tourism and better health in elderly people, which should be explored further.

Other limitations of our study that should be mentioned are those derived from the source of the sample: elderly people attending leisure centres. These leisure centres are common in Spain, and there elderly people attend to do exercise, to meet other older people, to undergo rehabilitation and therapy, to participate in workshops, amongst a range of other activities. This convenience sample limits the generalisability of the results, although it can explain the larger representation of tourists in the sample, and it may also explain the fact that the fourth hypothesis was not confirmed. Thus, the absence of differences in social integration between older people who participated in tourism from those who did not participate could be because all of them have a high level of social integration because they are already participating in social activities at the centre. Although alternative methods of obtaining access to older people were explored, these were unsuccessful, whereas the leisure centres provided safe and convenient access to sufficient numbers of diverse older people. Additionally, it would be wrong to assume that all people attending leisure centres are socially integrated because they may be attending as a consequence of being identified as needing social support intervention. However, further studies with random samples from the general population of elderly people are needed.

Ultimately, the results of our study provide empirical evidence supporting the positive effects of tourism on the 
health of older people. Additionally the paper offers a useful methodology for future studies which can be applied in a range of contexts over time.

\section{REFERENCES}

Alén ME, Domínguez T, Fraíz A. 2010. El turismo sénior como segmento de mercado emergente. Cuadernos de turismo 26: 9-24.

Alonso J, Regidor E, Barrio G, Prieto L, Rodríguez C, de la Fuente L. 1998. Valores poblacionales de referencia de la versión española del Cuestionario de Salud SF-36. Medicina Clínica 11 (111): 410-416.

Bagozzi RP, Yi Y. 2012. Specifications, Evaluation, and Interpretation of Structural Equation Models. Journal of the Academy of Marketing Science 40: 8-34.

Bentler PM. 2006. EQS 6 Structural Equations Program Manual. Multivariate Software, Inc. University of California, Los Angeles, USA: Encino, CA.

Bergier B, Bergier J, Kubinska Z. 2010. Environmental Determinants of Participation in Tourism and Recreation of People With Varying Degrees of Disability. Journal of Toxicology and Environmental Health 73: 17-18.

Berkman L, Syme, S. 1979. Social Networks, Host Resistance, and Mortality: A Nine-Year Follow-up of Alameda County Residents. American Journal of Epidemiology 109: 186-204.

Blichfeldt B, Nicolaisen J. 2010. Disabled Travel: Not Easy, but Doable. Current Issues in Tourism 1 (14): 74-102.

Chen CC, Petrick JF. 2013. Health and Wellness Benefits of Travel Experiences: A Literature Review. Journal of Travel Research 52(6): 709-719.

de Aguiar MC, Aibéo MJ, Kastenhols E, Dourado HM. 2012. Social Tourism Programmes: Report I. Universidade de Aveiro and Fundación INATEL, Portugal.

de Bloom J, Geurts SAE, Sonnentag S, Taris T, de Weerth C, Kompier MAJ. 2011. How Does a Vacation from Work Affect Employee Health and Well-Being? Psychology \& Health 26 (12): 1606-22

Diener E, Emmons R, Larsen RJ, Griffin S. 1985. The Satisfaction With Life Scale. Journal of Personality Assessment, 49: 71-75.

Dolnicar S, Yanamandram V, Cliff K. 2012. The Contribution of Vacations to Quality of Life. Annals of Tourism Research 39 (1): 59-83.

European Commission. 2009. The 2009 Ageing Report: Economic and Budgetary Projections for the EU Member States (2008-2060). European Economy N.2/2009.

European Innovation Partnership on Active and Health Ageing. 2011. Strategic Implementation Plan for the European Innovation Partnership on Active and Healthy Ageing. Steering group working document. Final text adopted by the steering group on 7/11/11. Operation plan, Brussels.

EESC. 2006. Opinion of the European Economic and Social Committee on Social Tourism in Europe (2006/C 318/12). Official Journal of the European Union C 318/67-77.

Eurostat. 2010. Work Session on Demographic Projections. Lisbon, 28-30 April 2010. Methodologies and Working Papers. European Commission: Luxemburg, ISSN 1977-0375.

Eurostat. 2012. Population Structure and Ageing. European Commission. Statistics Explained. Retrieved June 20, 2013, from the Eurostat Web site: http://epp.eurostat.ec.europa.eu/statistics_explained/index.php/Population_structure_and_ageing

Eurostat. 2013. Healthy Life Years. Retrieved, 15 July, 2013, from the Eurostat Web site: http://epp.eurostat.ec.europa.eu/statistics_ explained/index.php/Healthy_life_years_statistics

Ferri M. 2013. Sustainability of the social tourism policy: the selfassessment model of accessible social tourism. In J. Garcés, \& I. Monsonís (Eds.), Sustainability and Transformation in European Social Policy (pp. 253-272). Peter Lang: Oxford.
Ferri M, Durá E, Garcés J. 2013. Functional Health Benefits for Elderly People Related to Social Tourism Policy Promotion. International Journal of Multidisciplinary Social Sciences 1: 1-8.

Fleischer A, Pizam A. 2002. Tourism Constraints Among Israelí Seniors. Annals of Tourism Research 1(29): 106-123.

Garcés J, Mosonis I. 2013. Sustainability and Transformation in European Social Policy. Peter Lang International Academic Publishers: Oxford.

Garcés J, Ródenas F, Sanjosé V. 2004. Care Needs Among Dependent Population in Spain: An Empirical Approach, Health and Social Care in the Community 12 (6): 466-474.

Gibson H. 2002. Busy Travellers: Leisure Travel Patterns and Meanings in Later Life. World Leisure Journal 44 (2): 11-20.

Gilbert D, Abdullah J. 2004. Holidaying and the Sense of WellBeing. Annals of Tourism Research 1 (31): 103-121.

Glover P, Prideaux B. 2009. Implications of Population Aging for the Development of Tourism Products and Destinations. Journal of Vacation Marketing 15: 25-37.

Gump BB, Matthews KA. 2000. Are Vacations Good for Your Health? The 9-Year Mortality Experience After the Multiple Risk Factor Intervention Trial. Psychosomatic Medicine 62: 608-612.

Heene M, Hilbert M, Draxler C. Ziegler M. 2011. Masking Misfit in Confirmatory Factor Analysis by Increasing Unique Variances: A Cautionary Note in the Usefulness of Cutoff Values of Fit Indices. Psychological Methods 16 (3): 319-336.

Hobson JSP, Dietrich UC. 1995. Tourism, Health and Quality of Life. Journal of Travel \& Tourism Marketing 3(4): 21-38.

Iglesias-Souto PM, Dosil A. 2005. Algunos indicadores de percepción subjetiva implicados en la satisfacción del residente mayor. Propuesta de una escala de medida. Revista Española de Geriatría y Gerontología 40(2): 85-91.

IMSERSO. 2011. Social Tourism Inquiry. Retrieved December 23, 2012, from the Ministerio de Sanidad, Política Social e Igualdad Web site: http://nationbuilder.s3.amazonaws.com/ appgonsocialtourism/pages/23/attachments/original/IMSERSO_SOCIAL_TOURISM_INQUIRY.pdf?1314889620

Lawton MP, Brody EM. 1969. Assessment of Older People: SelfMaintaining and Instrumental Activities of Daily Living. Gerontologist 9: 179-186.

Lee SH, Tideswell C. 2005. Understanding Attitudes Towards Leisure Travel and the Constraints Faced by Senior Koreans. Journal of Vacations Marketing 3 (11): 249-263.

Lyons KS, Zarit SH, Sayer AG, Whitlatch CJ. 2002. Caregiving as a Dyadic Process: Perspectives from Caregiver and Receiver. Journal of Gerontology: Psychological Sciences 3: 195-204.

Martin L, Preston S. 1994. Demography of Ageing. National Academy Press: Washington, DC.

Matsuo M, Nagasawa J, Yoshino A, Hiramatsu K, Kurashiki K. 2003. Effects of Activity Participation of the Elderly on Quality of Life. Yonago Acta medica 46: 14-24.

McCabe S. 2009. Who Needs a Holiday? Evaluating Social Tourism. Annals of Tourism Research 36 (4): 667-668.

McCabe S, Johnson S. 2013. The Happiness Factor in Tourism: Subjective Well-Being and Social Tourism. Annals of Tourism Research 41: 42-65.

McGuire FA. 1984. A Factor Analytical Study of Leisure Constraints in Advanced Adulthood. Leisure Sciences 6 (3): 313-326.

Milman A. 1998. The Impact of Tourism and Travel Experience on Senior Travelers' Psychological Well-Being. Journal of Travel Research, 37 (2): 166-70.

Minnaert L, Maitland R, Miller G. 2009. Tourism and Social PolicyThe Value of Social Tourism. Annals of Tourism Research 36 (2): 316-334.

Minnaert L, Schapmans M. 2009. Tourism as a Form of Social Intervention: The Holiday Participation Centre in Flanders. Journal of Social Intervention: Theory and Practice 18 (3): 42-61.

Neal JD, Sirgy JM, Uysal M. 1999. The Role of Satisfaction with Leisure Travel/Tourism Services and Experience in Satisfaction 


\section{J. G. Ferrer et al.}

with Leisure Life and Overall Life. Journal of Business Research 44 (3): 153-63.

Nimrod G. 2008. Retirement and Tourism, Themes in Retirees' Narratives. Annals of Tourism Research 5 (4): 859-878.

Ortega E. 1989. Las vacaciones de los españoles de la tercera edad. Estudios Turísticos 102 (6): 75-111.

Paulo P, Carrasco M, Cabezas M, Gac H, Hoyl T, Duery P, Petersen K, Dussaillant K. 2004. Impacto biomédico de los viajes en adultos mayores chilenos. Rev Méd Chile 132: 573-578.

Price Waterhouse Coopers. 2004. Estudio sobre el programa de vacaciones para mayores del IMSERSO. Price Waterhouse Coopers.

Querejeta. 2004. Discapacidad/dependencia: unificación de criterios de valoración y clasificación. Madrid: Ministerio de Trabajo y Asuntos Sociales.

Quinn B, Griffin K, Stacey J. 2008. Poverty, Social Exclusion and Holidaying: Towards Developing Policy in Ireland. Retrieved December 15, 2012, from the Combat Poverty Agency Web site: http://www.cpa.ie/publications/workingpapers/2008-01_WP_ PovertySocialExclusionAndHolidaying.pdf.

Sanjoaquín AC, Fernández E, Mesa P, García-Arilla E. (2007). Valoración geriátrica integral. In Sociedad Española de Geriatría y Gerontología (Eds.), Tratado de Geriatría para residentes (pp.59-68). Sociedad española de Geriatría: Madrid.

Schröder A, Widmann T. 2007. Demographic Change and its Impact on the Travel Industry: Oldies-Nothing but Goldies? In R. Conrady \& M. Buck (Eds.), Trends and Issues in Global Tourism (pp.3-17). Springer: Berlin and Heidelberg.

Sedgley D, Pritchard A, Morgan N. 2011. Tourism and Aging: A Transformative Research Agenda. Annals of Tourism Research 33 (2): 422-496.

Sirgy MJ. 2010. Toward a Quality-of-Life Theory of Leisure Travel Satisfaction. Journal of Travel Research 49 (2): 246-60.
Statts S, Pierfelice L. 2003. Travel: A Long-Range Goal of Retied Women. The Journal of Psychology 137 (5): 483-494.

Vilagut G, Ferrer M, Rajmil L, Rebollo P, Permanyer-Miralda G, Quintana JM, Santed, R, Valderas JM, Ribera A, DomingoSalvany A, Alonso J. 2005. El cuestionario de Salud SF-36 español: una década de experiencia y nuevos desarrollos. Gaceta Sanitaria 19 (2): 135-150.

Ware JE, Kosinski M, Turner-Bowker D, Sundaram M, Gandek, B, Maruish ME. 2009. SF 12v2 Health Survey: Administration Guide for Clinical Trial Investigators. Quality Metric Incorporated: Lincoln.

Weiss R. 2005. The Experience of Retirement, Ithaca, Cornell University Press: NY.

Wei S, Milman A. 2002. The Impact of Participation in Activities While on Vacation on Seniors' Psychological Well-Being: A Path Model Application. Journal of Hospitality \& Tourism Research 26 (2): 175-85.

World Health Organisation. 1946. Preamble to the Constitution of the World Health Organization as adopted by the International Health Conference, New York, 19-22 June, 1946; signed on 22 July 1946 by the representatives of 61 States (Official Records of the World Health Organization, no. 2, p. 100) and entered into force on 7 April 1948.

World Health Organization. 2001. International Classification of Functioning, Disability and Health. World Health Organisation: Geneva.

World Health Organisation. 2002. El envejecimiento saludable. El envejecimiento y la actividad física en la vida diaria. Programa sobre Envejecimiento y Salud. World Health Organisation: Geneva.

World Health Organization. 2011. Chronic Diseases and Health Promotion. Retrieved October 20, 2011, from the World Health Organisation Web site: http://www.who.int/chp/en/

\section{APPENDIX}

\section{Items used for the cluster analysis to identify tourists and non-tourists in our study:}

1. Do you travel?

2. How many travels did you do last year?

3. How many of these travels were excursions?

4. In how many of these travels have you spend one night?

5. And in how many more than two nights?

6. Where did you stay?

7. Which information resource have you used to prepare these travels?

8. What were your reasons to travel?

9. With whom do you prefer to travel?

10. Do you often travel with package journeys?

11. In which season do you prefer to travel?

12. Why?

13. Which transport do you prefer to use?

14. In which mode of transport do you find more barriers?

\section{Abbreviate items of the SF-12 (Ware et al., 2009):}

- Moderate activities, such as moving a table, pushing a vacuum cleaner, bowling or playing golf

- Climbing several flights of stairs

- Accomplished less than you would like

- Limited in kind of work or other activities

- Extent pain interfered with normal work

- Is your health: excellent, very good, good, fair or poor

- Have a lot of energy

- Frequency that health problems interfered with social activities 
- Accomplished less than you would like

- Did work or other activities less carefully than usual

- Felt calm and peaceful

- Felt downhearted and depressed

\section{Abbreviated items of the Lawton and Brody Index (1969):}

- Ability to use telephone

- Shopping

- Food preparation

- Housekeeping

- Laundry

- Mode of transportation

- Responsibility for own medications

- Ability to handle finances

\section{Items of the Diener Scale (Diener et al., 1985):}

- In most ways my life is close to my ideal.

- The conditions of my life are excellent.

- I am satisfied with my life.

- So far I have gotten the important things I want in life.

- If I could live my life over, I would change almost nothing.

- Items of the Berkman-Syme.

\section{Abbreviated items of the Berkman-Syme index (1979):}

- Marital status

- Number of close friends to talk about private matters

- Frequency to meet with close friends

- Number of relatives to talk about private matters

- Frequency to meet with relatives

- Participation in groups

- Participation in religious meetings or services

- Number of people to talk

- Number of people to receive piece of advice

- Number of people who loves the surveyed person

- Number of people to support the surveyed person

- Number of people who the surveyed person can trust 